\title{
Evaluating ocean carrier selection criteria: perspectives of Tasmanian shippers
}

\author{
Peter Dzakah FANAM ${ }^{1 *}$ (D) and Leigh ACKERLY²
}

\author{
* Correspondence: peter.fanam@ \\ utas.edu.au \\ ${ }^{1}$ University of Tasmania the \\ Australian Maritime College, \\ Australia, 28 Treherne Street, \\ Launceston, Tasmania 7248, \\ Australia \\ Full list of author information is \\ available at the end of the article
}

\begin{abstract}
The purpose of this paper is to evaluate the decision process of Tasmanian shippers when selecting an ocean carrier. Data collected through an internet-based survey is described, and influential selection criteria are reported with the use of exploratory factor analysis. The findings indicate that Tasmanian shippers are both price and service conscious. Tasmanian shippers, unlike their mainland Australian counterparts, have an overwhelming reliance on maritime transportation.

The exploratory factor analysis indicates that service takes precedence over price for the subjects of the study. The findings indicate that network and schedule reliability and corporate social responsibility are influential in the choice of ocean freight services. Cargo security and seasonal capacity availability are similarly influential to Tasmania shippers.

The study provides insight into the decision-making process of Tasmanian shippers. In this function, it may benefit Tasmanian ocean freight service providers by describing the characteristics that Tasmanian shippers find desirable in selecting between competing carriers. Thus, ocean freight service providers can formulate necessary strategies to attract Tasmania shippers to purchase their liner services.

Keywords: Shippers, Tasmania freight, Freight forwarders, Ocean carriers, Selection criteria, Container service, Price attributes, Service attributes
\end{abstract}

\section{Introduction}

The decision-making process employed by shippers when selecting from competing ocean carriage services has received considerable attention in transportation research. Shippers use various decision criteria when making a selection of an ocean carrier. The carrier may be either a vessel owning or a non-vessel owning common carrier (NVOCC forthwith), for example, freight forwarding services.

NVOCCs such as freight forwarders offer comprehensive shipping and ancillary services. Moreover, they are acknowledged by vessel-owning carriers as an important source of cargo. Arguably, shippers may decide to utilise the services of an NVOCC as a 'one-stop' shipping solution, leveraging the freight forwarder's expertise to simplify their shipping process. Alternatively, shippers may decide to contract an ocean carrier directly.

It is suggested that the decision-making processes of shippers when selecting a carrier are underpinned by two primary decision alternatives, each with various component criteria. Broadly, these can be divided into price-based and service-based decision

(c) The Author(s). 2019 Open Access This article is distributed under the terms of the Creative Commons Attribution 4.0 International License (http://creativecommons.org/licenses/by/4.0/), which permits unrestricted use, distribution, and reproduction in any medium, provided you give appropriate credit to the original author(s) and the source, provide a link to the Creative Commons license, and indicate if changes were made. 
criteria. Shippers may be influenced by either, or both, to varying degrees. Price-based decisions concern the level, stability and flexibility of the freight rate. Service-based decisions concern the carrier's reliability, network and schedule, cargo handling capabilities, customer service attributes, corporate social responsibility, and ability to provide ancillary services if required.

Transport research has examined carrier selection criteria over several decades. Research has been conducted in various localised contexts. Pearson (1980) studied carrier selection factors in the United Kingdom. Brooks (1995) studied North Atlantic shipping in the context of the United States, Canada and Europe. Many studies have been conducted in Asia. Tiwari et al. (2003) and Wong et al. (2008) studied Chinese shippers. Shang and Lu (2012) studied Taiwan. Banomyong and Supatn (2011) and Setamanit and Pipatwattana (2015) examined Thailand. Indian shippers were studied by Kannan et al. (2010). Fanam et al., 2016b examined the carrier selection perspectives of freight forwarders in Ghana. Few academic literatures examining carrier selection criteria in an Australian context. However, none have considered carrier selection from Tasmania perspective. To the best of the authors' knowledge, the selection of ocean carriers has not been examined in a Tasmanian context. This is understandable, due to Tasmania's insignificant cargo volume by world standards. Regardless, Tasmania is unique in Australia, utilising both containerised services and Ro-Ro trailers. Thus, research into ocean carrier selection in a Tasmanian context appears warranted. Therefore, the purpose of this paper is to evaluate and discuss the decision criteria of shippers in context of the Australian island state of Tasmania, in order to identify which carrier selection criteria influence Tasmanian shippers of containerised and transported-in-trailer cargoes when selecting from competing shipping services.

In consideration of the recent increase in competition and potential future service expansion, an investigation into the decision-making process of Tasmanian shippers when selecting from competing ocean carriers appears warranted.

Tasmania's freight volume is heavily reliant on short-sea shipping, with $99 \%$ of cargo destined interstate or overseas carried by sea (Department of State Growth Tasmania 2019). At present, there are no direct international liner services calling Tasmanian ports. Tasmanian shipping services are currently delivered by frequent services operating between the Victorian port of Melbourne and the northern Tasmanian ports of Burnie, Devonport and Bell Bay. These services operate using both dedicated container and ro-ro vessels. Additionally, a significant portion of Tasmania's time-sensitive interstate cargo is transported in refrigerated trailers on the Bass Strait ferry service operating between Devonport and Melbourne.

Containerised and transported-in-trailer cargo constitutes approximately $40 \%$ of Tasmania's freight task. In 2017/18, Tasmania's total container volume was slightly above 550,000 twenty-foot equivalent unit (TEU). By weight, containerised cargo represented approximately 6.2 million tonnes. Tasmania's containerised freight volume has not increased significantly in the last decade (Tasmania Department of State Growth 2019).

Despite slow growth in cargo volume, competition for the Tasmanian sea freight market has increased. Moreover, ongoing discussion concerning the viability of reintroducing direct international liner services to Tasmania attracts commentary from both public and private sectors (Kelly 2016; Mounster 2017). It is suggested that these factors indicate confidence in Tasmania's current and future market potential for seaborne 
trade. Presently, there is only three shipping lines (Toll, SeaRoad and TT-Line) running a daily transport services on Bass Strait conveying cargo between Tasmania and the mainland (Melbourne). There is no international line calling Tasmania, the movement of freight is carried by the local transport operators. Toll carried $55 \%$ of the trade volume, SeaRoad 24\%, while TT-Line carried 21\%. Tasmania businesses are supported by the state government. In 1976, the Australian government introduced the Tasmanian Freight Equalisation Scheme to accommodate and provide some compensation to Tasmanian businesses for exporting outside the state (Albanese 2012). From 1976 to 2011, the scheme has cost 2.6 billion dollars based on the dollar value in 2010. This scheme is vital to supporting Tasmanian exporters. Hidding (2016) noted that the container shipping constituted the single largest costs, that is, $65 \%$ of transportation cost in the supply chain of Tasmania and the container freight rate per TEU through the Bass Strait can fluctuate anywhere typically between $\$ 600$ to $\$ 1200$ depending upon seasonal outcomes and external factors.

Tasmania as a state over the last 5 years has experienced a growth in the volume of exports and imports with a 20.2\% increase in exports between the 2013-14 and 2015-16 Department of Foreign Affairs and Trade (DFAT) (2017). In 2015-16, the average utilisation for exports was $88 \%$ and $86 \%$ for imports, which is above the target effective operating capacity of $85 \%$ utilisation. This shows that at the current operating capacity; Tasmanian ports are handling and working above the effective target and represents the need for additional services (Tasmanian Government 2017).

Because of this growth in freight movement and inefficient operations within Tasmanian ports, the three Major maritime transport operator's, TT-line (spirit of Tasmania), Toll and SeaRoad have undertaken strategies to address the increases in freight movements (Tasmanian Government 2017). In the case of Toll and SeaRoad, both companies have chosen to expand their service fleet within Tasmania by each company introducing a new vessel into their operations which SeaRoad achieved in 2017 and Toll's new vessel arrived in early 2019 (Tasmanian Government, Department of State Growth 2019) as a result of the additional vessels operating out of Tasmania, container capacity is set to increase by over 275,000 TEUS one way.

In both Tasmania and Australia, the maritime trade is showing strong growth partly due to population growth. The current population trends show an increase of $2.1 \%$ in 2018, signifying potential growth for maritime trade (Australian Bureau of Statistics 2019). Thus, warranting a research into ocean carrier selection from the Tasmanian perspective.

\section{Carrier selection criteria in academic literature}

Ocean carrier selection criteria have attracted considerable attention in academic study. This study spans several decades. Arguably, containerised freight transportation has been subject to a paradigm shift in service expectation and delivery in the period in which these studies have been conducted. Consequentially, the decision criteria of shippers may have changed over time, in parallel with their service needs.

In an extensive early study, Pearson (1980) evaluated carrier selection criteria in the context of shippers in the United Kingdom. Continuity, certainty, frequency and reliability were identified as highly important to shippers. This early study gave weight to service-based criteria being highly influential. In support of this, Pearson (1980) 
observed that UK shippers overwhelmingly favoured liner conference services, for the reasons stated above, despite the price increase over non-conference services.

In a further study, Brooks (1995), examines ocean carrier's core service, performance metrics, and service delivery attributes as selection criteria. Brooks' (1995) study utilised a random quota of shippers obtained from a carriers list. Importantly, this study was representative of different participant groups-shippers with varying scales of operations, and freight forwarders. This study is regarded as important to this research, as further distinction was made between price and service attributes as influencers, depending on the size of the shippers' operations. The size of shippers' operations was also found to be influential by Wong et al. (2008), Setamanit and Pipatwattana (2015) and Fanam et al. (2016a).

\section{Short sea shipping}

Bendall and Brooks (2010) importantly review Short Sea Shipping in Australia and highlight the competitive nature of Short Sea Shipping. Significantly, reviewing available literature, which will greatly assist the research project in providing what the government needs to do to influence shippers to switch from land modes to coastal shipping, is vital. This is a critical aspect in evaluating how well unmanned shipping may work in Australian domestic freight transport as to generate success, there will need to be a major freight transport mode switch.

Bendall and Brooks (2010) are effective in illustrating the various segments of Australian domestic freight movements, highlighting the patterns and more importantly, which road corridors of freight movement the Australian coastal shipping can compete with. Furthermore, this resource emphasized where SSS is unlikely to be competitive to road freight (e.g. intra-state freight). This is important and saves time for the researcher in narrowing down where the unmanned shipping would likely be effective in Australia and how, which is a large bulk of the transport research project.

The biggest hindrance to Australia coastal shipping trade is high levels of cabotage and the red tape in politics to proposing any reforms to existing legislation (Berg, 2017). Recent studies by Brooks (2014) and (2015) and Porter (2015) have considered the current reforms and legislation of coastal shipping. Brooks (2015), found that there is promise for coastal shipping but not under the current legislation with more open regulation needed (Brooks, 2015). Brooks (2014), found that the need for changes in reforms would result in hardship for shippers in becoming competitive. Porter (2015), supports Brooks (2014) realisation that reforms have not been enough to revitalise Australian coastal shipping, and that government efforts have not been adequate or long term to support a competitive coastal trade.

Coastal shipping is important to Tasmania with $99 \%$ of freight being moved by shipping (Brindley, 2016). It is restricted by geographical hindrance and requires specialty shipping. The use of Ro-Ro vessels for containerised trade has aided in Tasmania being economically viable, but higher costs of cabotage still inflict pain in the overall supply chain (Ballantyne, 2014). Articles from BITRE (2015), Brindley (2016) and Deegan (2012), all indicate economic stresses that Coastal Trading Act place on the exports and imports of Tasmania. Brindley (2016) goes to the extent to suggest the government should treat Tasmania as a special case with regulation. This indicates that reforms make it nearly economically not viable. 


\section{Sensitivity to price and service-based attributes}

It can hardly be disputed that service reliability is critically important to shippers. Transit time, schedule frequency and schedule reliability are regularly identified as commonly influential carrier selection criteria (Wong et al., 2008; Saldanha et al. 2009; Chung \& Chiang 2011; Maloni, Gligour \& Lagoudis 2013; Setamanit \& Pipatwattana 2015; Fanam et al., 2016b. It is suggested that these attributes may prove highly influential to Tasmanian shippers, due largely to the considerable amount of time-sensitive fresh produce exported Department of State Growth (Tasmania) (2015). Other service-based attributes identified concern cargo, such as the accuracy of shipping documentation (Banomyong \& Supatn 2011).

Other service-based attributes examined in the literature include communication and problem-solving capability (Brooks 1995; Shang \& Lu 2012). These could arguably be considered basic attributes of any service provider and highly likely to be important to the customer. Information technology, in the form of web-based electronic data exchange, was found to be influential by Premeaux (2007), albeit in the context of motor carriers and shippers. It is suggested that this criterion is important, considering the requisite for connectivity and real-time information exchange prevalent in the modern business environment.

Many shippers may remain highly price-sensitive. Price sensitivity was identified in the early study by Pearson (1980), and again by Brooks (1990, 1995). Subsequent studies by Kent and Parker (1999) and Kannan et al. (2010) identify freight rate as a carrier selection criterion, with the latter study also identifying flexibility of freight rate as an influential decision criterion.

Price sensitivity is of considerable interest to this study. Tasmanian shippers have historically assumed a cost burden due to the ocean carriage leg in their freight task. This has been mitigated to a degree by government subsidy in the form of the Tasmanian Freight Equalisation Scheme (Australian Government 2017).

\section{THE EMERGING ROLE OF NVOCCS}

Brooks (1990) observed that research contribution to the methodology of carrier selection had remained largely unchanged in the decade since Pearson (1980), and made mention of the changing practice in carrier selection of delegating the procurement of ocean carriage to a third party. This was an acknowledgment of the growing role of freight forwarders and third-party logistics providers. Arguably, the role of third parties in ocean carriage is far more pronounced today, almost three decades after this study Fanam et al. (2016c).

It is further suggested that shippers today may blur the distinction between vessel owners and NVOCCs as 'carrier'. The use of freight forwarding services could be motivated by many factors, such as price and service, convenience and shipping experience. Shippers with less experience and door-to-door service requirements may decide to delegate their land and sea freight requirements to a third-party logistics provider, leveraging their expertise and strong connections with ocean carriers to simplify their logistics service requirements.

Increasing demand is being placed on carriers to provide door-to-door logistics services for time-sensitive shippers (Cariou 2008). Meixell and Norbis (2008) suggest 
increasing supply chain integration by oceans carriers introduces new paradigms to carrier selection decision-making. Fanam et al. (2016b) note that supply chain integration and ability of the carrier to offer door-to-door service are underrepresented in academic literature. This is of considerable interest to this study, as is the ability of the carrier to provide seamless integration with land-side logistics operations.

The literature subjected to review provides insightful, credible and historical insight into the decision alternatives of shippers when selecting from competing ocean container carriers. The only perceived limitations are the (current) scarcity of literature addressing the positioning of ocean carriers as providers of door-to-door services, as identified by Fanam et al. (2016b), and discussion of alternative transportation and unitisation methods, such as refrigerated trailers on Ro-Ro vessels.

\section{Methodology}

The survey instrument was designed to collect information from the Tasmania shippers to enable the researchers to analyse the important selection criteria consider by shippers.

The survey instrument was based on the carrier selections items that researchers considered important during 2010-2018. A panel of three academics and three industrial professionals was formed to review the survey questions and based on panel discussions four items were added, that is, 'Carrier's stated or perceived commitment to Tasmanian services, Refrigerated container or trailer capability, Domestic service network and Schedule frequency (e.g. sufficient number of sailings per week)'. These items were added due to the growing recent debate from the community and stakeholders in Tasmania. Pre-testing was conducted using experts in the field including ten academics from the University of Tasmania, seven shippers and four professionals from the shipping industry. Pretesting was undertaken to ensure the data collection instrument for the study was appropriate for the respondents and that the terminology and questions would be understood by the sample. Therefore, the survey questionnaire for the current study was designed based on the contemporary literature review and discussion with academics and professionals in the maritime industry in Tasmania which resulted in the identification of the 17 carrier selection elements.

Data collection was conducted by a webpage survey built in Google Forms. To gather a list of 200 respondents, information was obtained from publicly available sources including the Buy from Tasmania Directory (Brand Tasmania/Tasmanian Government, 2017). The survey organised decision criteria into Likert-type questions. The questions utilise a 5-point scale ranking of importance. The survey participants were asked to indicate their level of agreement on a five scale of ' 1 ' not important, and ' 5 ' very important. A pre-notification email was sent to all 200-target sample two weeks in advance to introduce the research topic to the respondents. The survey was distributed via an email link, with an accompanying information sheet and consent form. Due to the anonymity of respondents and no request for company-sensitive data, consent was implied by the respondents' participation.

The total valid of 46 responses were received representing response rate of $23 \%$ due to email survey used. It is acknowledged that cold-surveying via email may result in low participation rates. This may be due to the survey recipients' lack of time, or adversity to unsolicited email contact of a non-business nature. A reminder email was sent 
two weeks after initial contact resulting in a slight increase in the response rate to achieve the valid response rate of $23 \%$.

\section{Data analysis and findings}

The aim of the analysis is to attempt to determine the level of influence on shippers of the selection criteria presented in the survey. This section reported the survey response rate and describe the data collected. Moreover, it will report the results of analysis of reliability of the Likert-type data collected. Descriptive statistics will be used to report the influence of various carrier selection criteria. Findings will be reported in the following groups: procurement of shipping services, description of cargo, shipping experience, pricing of service, network and schedule service-based criteria, cargo service-based criteria, and corporate social responsibility-based criteria.

\section{Procurement of shipping services}

Survey respondents were asked to describe their preferred method of procuring shipping services, either through a freight forwarder or by booking directly with the carrier. As shown in Fig. 1, responses to this question revealed that $65 \%$ of respondents' procured freight services through a freight forwarding service, $31 \%$ booked directly with the ocean carrier and $4 \%$ elected to decline to provide this information.

The findings concur with the prevalence of NVOCCs identified in the literature review (Meixell \& Norbis 2008). It is a distinct possibility that freight forwarders are regarded as 'carrier' by Tasmanian shippers. The conceptual framework indicates that this may preclude the specific choice of ocean carrier by the shipper. Instead, the shipper is reliant on the freight forwarder's expertise and network.

\section{Description of cargo}

Survey respondents were asked to describe their cargo. Responses to this question demonstrated a variety of cargo. Figure 2 shown the view of survey respondents, containerised and cargo transported in trailer were split quite evenly when aggregated, at $52 \%$ and $48 \%$ respectively. This provides an interesting picture of Tasmanian cargo unitisation and justifies the research scope being extended to cargo transported in trailers.

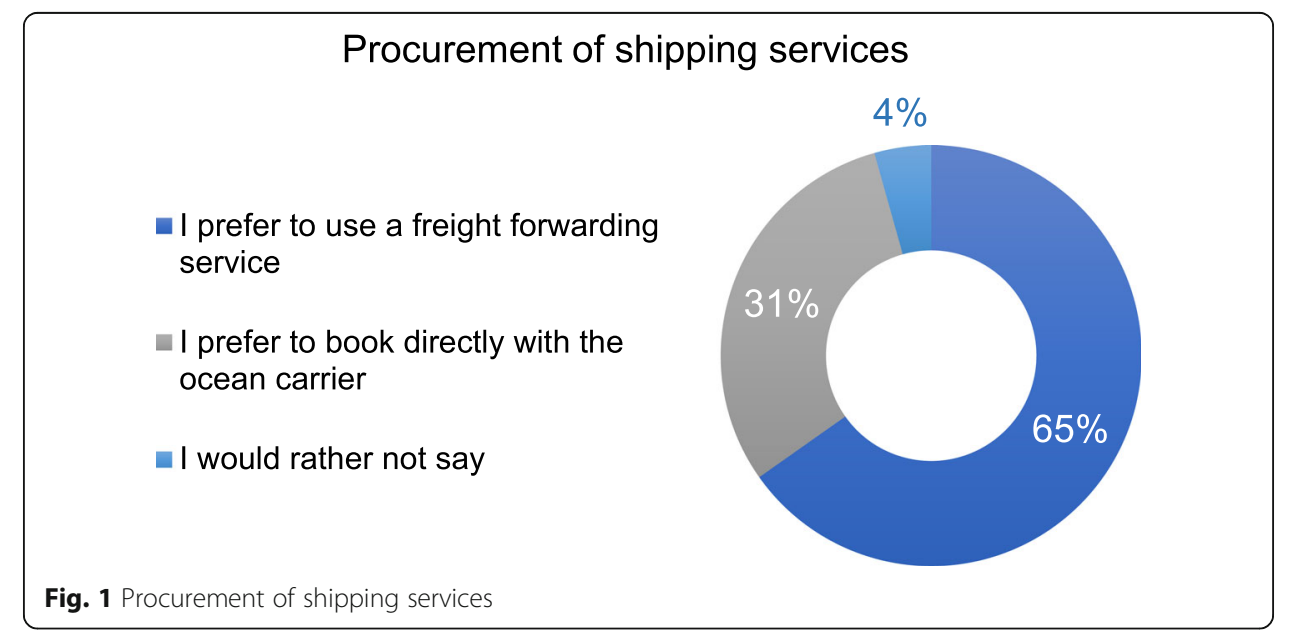




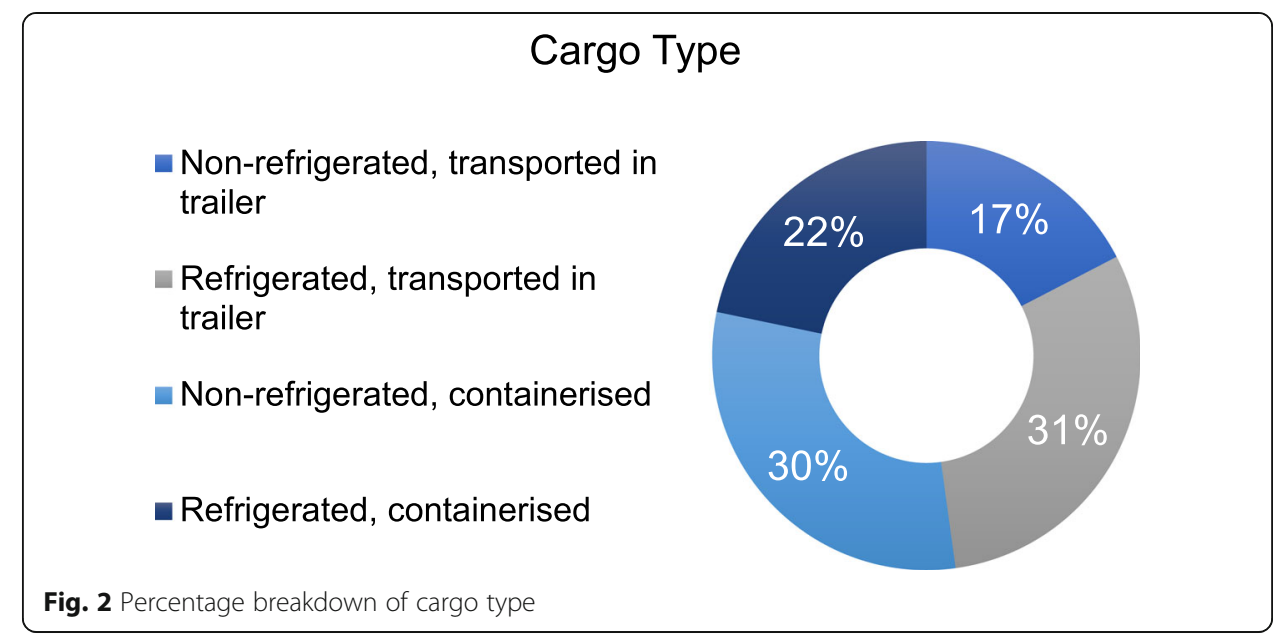

The data reports that more refrigerated cargo is transported on trailers (31\%) than in containers (22\%). Conversely, non-refrigerated cargo is more likely to be containerised.

\section{Shipping experience}

Survey respondents were asked to describe their years of experience with Tasmanian shipping services. Figure 3 revealed the outcome of respondents with $57 \%$ of the respondents have been utilising services for over ten years, $9 \%$ between five and ten years, $26 \%$ between one and five years, and one for less than a year. One respondent declined to provide this information. It is suggested that the majority of respondents are experienced in dealing with shipping service providers and are therefore mindful of price and service-based concerns.

\section{Analysis of carrier selection CRITIERIA}

Cronbach's Alpha coefficient was used to test the reliability test. This describes the extent to which survey items measure the same concept or construct and the extent to

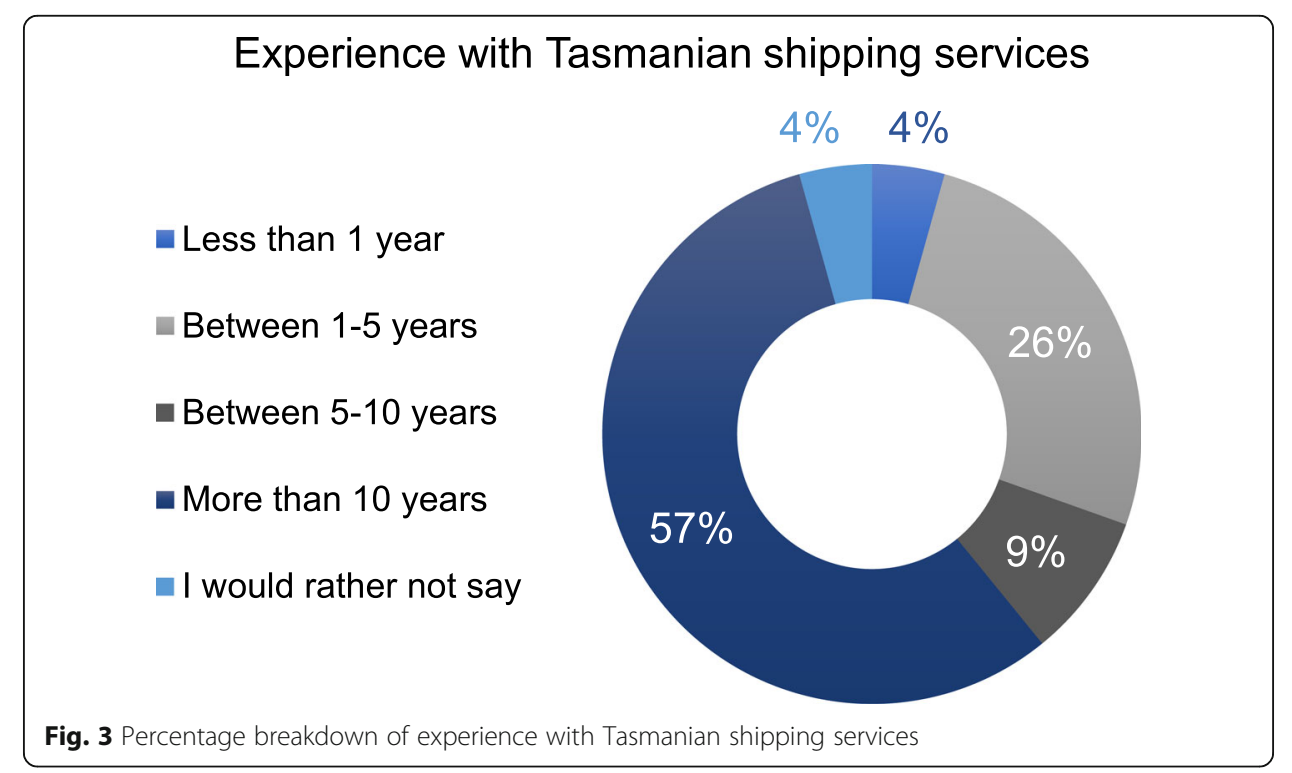


which they are inter-related (Tavakol \& Dennick 2011). The Cronbach's Alpha coefficient values for each of the 5 components concerning shippers' selection of ocean carrier were $0.758,0.782,0.568,0.861$ and 0.858 for pricing of service, network \& schedule, door-to-door service, cargo and corporate social responsibility respectively (see Table 1). Thus indicating an acceptable-to-good level of internal consistency in each category, denoting that the identified variables are strongly measuring the same construct.

Table 2 shows the descriptive statistics of each of the 17 variables investigated included median, mode and missing. The responses were measured on a five-point Likert scale, hence, the median showed the trend of responses for each item that shows approximately $48 \%$ of responses at scale 5 (very important) and the rest on scale 4 . Thus, indicating a high level of awareness among the respondents on the factors affecting ocean carrier's selection criteria within the Tasmania context.

Table 3 presents the rotated pattern matrix of the five factors in exploratory factor analysis (EFA), indicating a simple structure, with each item loading high on only one of the five factors. The convergent validity of EFA was conducted to ensure that the component loadings of all items were $>.5$, being highly correlated with the concerned factor.

The five components (factors) namely pricing of service, network and schedule, door-to-door service, cargo and corporate social responsibility contained 17 items with factor loadings above 0.6 as indicated in (Table 3).

\section{Pricing of service}

The first factor, 'pricing of service' contained three items with associated item statements being 'lowest possible freight rate ', 'stability of freight rate ', and 'flexibility of freight rate'. The data indicated that pricing of service is an important decision criterion for Tasmanian shippers, with data reporting a consistent mode of 5 (very important). Of the three item statements, lowest possible freight rate demonstrated the most influence with the highest factor loading of (.783) and conresponding median response of 5 (very important). Thus, indicating that Tasmania shippers consider lowest freight rate very important in their choice of ocean carrier. This is not surprising as Tasmania shippers heavily depend on interstate transportation for $99 \%$ of freight movement. This result is similar to the government findings and as a result, government is subsidising transport cost in Tasmania. The literature review identified freight rates as a common decision-making criterion for shippers. Moreover, other price-based characteristics were identified such as flexibility and stability of freight rates are also important to Tasmania shippers.

Table 1 Cronbach's alpha

\begin{tabular}{ll}
\hline Category & Cronbach's alpha \\
\hline Pricing of service & .758 \\
Network \& schedule & .782 \\
Door-to-door service & .568 \\
Cargo & .861 \\
Corporate social responsibility & .858 \\
\hline
\end{tabular}


Table 2 Five Components Rotated - Pattern Matrixa

\begin{tabular}{|c|c|c|c|c|c|}
\hline \multirow[t]{2}{*}{ Items } & \multicolumn{5}{|c|}{ Component } \\
\hline & $\begin{array}{l}\text { Pricing of } \\
\text { service }\end{array}$ & $\begin{array}{l}\text { Network \& } \\
\text { schedule }\end{array}$ & $\begin{array}{l}\text { Door-to-door } \\
\text { service }\end{array}$ & Cargo & $\begin{array}{l}\text { Corporate social } \\
\text { responsibility }\end{array}$ \\
\hline Lowest possible freight rate & 0.783 & & & & \\
\hline Stability of freight rate & 0.715 & & & & \\
\hline Flexibility of freight rate & 0.602 & & & & \\
\hline Domestic service network & & 0.782 & & & \\
\hline International service network & & 0.751 & & & \\
\hline $\begin{array}{l}\text { Schedule reliability (on-time arrival } \\
\text { and departure) }\end{array}$ & & 0.746 & & & \\
\hline $\begin{array}{l}\text { Schedule frequency (e.g. sufficient number } \\
\text { of sailings per week) }\end{array}$ & & 0.731 & & & \\
\hline Transit timeframe & & 0.728 & & & \\
\hline $\begin{array}{l}\text { Ability to provide integrated door-to-door } \\
\text { service }\end{array}$ & & & 0.701 & & \\
\hline $\begin{array}{l}\text { Integration and co-ordination with land-based } \\
\text { logistics operations }\end{array}$ & & & 0.681 & & \\
\hline Capacity availability & & & & 0.869 & \\
\hline Seasonal capacity availability & & & & 0.848 & \\
\hline Cargo security and safety & & & & 0.872 & \\
\hline Refrigerated container or trailer capability & & & & 0.851 & \\
\hline Perceived reputation of carrier & & & & & 0.817 \\
\hline $\begin{array}{l}\text { Carrier's stated or perceived commitment to } \\
\text { Tasmanian services }\end{array}$ & & & & & 0.808 \\
\hline Problem-solving capability & & & & & 0.795 \\
\hline
\end{tabular}

Extraction Method: Principal Component Analysis

Rotation Method: Oblimin with Kaiser Normalization

a. Rotation converged in 17 iterations

Tasmania shippers consider stability of freight rate, that is, their ability to lock in freight rates for a specified and/or extended period of time and flexibility of freight rate which denotes potential for volume and timing discounts. This finding is similar to the findings of other similar studies which also affirmed the long stand view of Tasmania as heavy dependant on interstate transport.

The summarised category median response of 4 indicates that pricing of service is considered important by Tasmanian shippers. As identified in the literature review, Tasmanian shippers assume somewhat of a cost burden in comparison to their mainland Australian counterparts. Thus, the investigation into Tasmanian shippers price-sensitivity, as suggested in the literature review, is justified.

\section{Network and schedule}

Network and schedule factor contained five items with associated item statements being 'domestic service network,' 'international service network,' 'schedule reliability (on-time arrival and departure),' 'schedule frequency (e.g. sufficient number of sailings per week)' and 'transit timeframe' with corresponding factor loadings of 0.782, 0.751, 0.746, 0.731, and 0.728 respectively. The result of the exploratory factor analysis revealed that network and schedule is very important for Tasmanian shippers when making a decision in choosing 
Table 3 Descriptive statistics

\begin{tabular}{llll}
\hline Item statements & Median & Mode & Missing \\
\hline Lowest possible freight rate & $\mathbf{5}$ & $\mathbf{5}$ & $\mathbf{0}$ \\
Stability of freight rate & $\mathbf{4}$ & $\mathbf{5}$ & $\mathbf{0}$ \\
Flexibility of freight rate & $\mathbf{4}$ & $\mathbf{5}$ & $\mathbf{0}$ \\
Domestic service network & $\mathbf{5}$ & $\mathbf{5}$ & $\mathbf{0}$ \\
International service network & $\mathbf{4}$ & $\mathbf{4}$ & $\mathbf{0}$ \\
Schedule reliability (on-time arrival and departure) & $\mathbf{5}$ & $\mathbf{5}$ & $\mathbf{0}$ \\
Schedule frequency (e.g. sufficient number of sailings per week) & $\mathbf{4}$ & $\mathbf{5}$ & $\mathbf{0}$ \\
Transit timeframe & $\mathbf{4}$ & $\mathbf{5}$ & $\mathbf{0}$ \\
Ability to provide integrated door-to-door service & $\mathbf{5}$ & $\mathbf{5}$ & $\mathbf{0}$ \\
Integration and co-ordination with land-based logistics operations & $\mathbf{5}$ & $\mathbf{5}$ & $\mathbf{0}$ \\
Capacity availability & $\mathbf{4}$ & $\mathbf{5}$ & $\mathbf{0}$ \\
Seasonal capacity availability & $\mathbf{3}$ & $\mathbf{5}$ & $\mathbf{0}$ \\
Cargo security and safety & $\mathbf{5}$ & $\mathbf{5}$ & $\mathbf{0}$ \\
Refrigerated container or trailer capability & $\mathbf{3}$ & $\mathbf{1}$ \\
Perceived reputation of carrier & $\mathbf{4}$ & $\mathbf{4}$ & $\mathbf{0}$ \\
Carrier's stated or perceived commitment to Tasmanian services & $\mathbf{4}$ & $\mathbf{4}$ & $\mathbf{0}$ \\
Problem-solving capability & $\mathbf{5}$ & $\mathbf{5}$ & $\mathbf{0}$ \\
\hline
\end{tabular}

ocean carrier, with data reporting a consistent mode of 5 (very important). Of the five-item statements, domestic service network demonstrated the most influence with the highest factor loading of (.782) and corresponding median response of 5 (very important).

Network and schedule were identified in the literature review as major decision criteria in ocean carrier selection. Schedule reliability was most frequently reported to be influential to Tasmanian shippers, with $61 \%$ respondents describing it as very important. This concurs with its prevalence in the literature review as a common key factor of importance. Summarised, all data in this category reported a median response of 5 , indicating that these factors are considered very important by Tasmanian shippers. This observation strongly supports the findings of other researchers, as identified in the literature review. The median response is higher than that of the previous category, pricing of service. Thus, it can be concluded that these service-based characteristics are of greater importance than price to Tasmanian shippers.

\section{Door-to-door service}

The door-to-door factor is associated with question statements about the ability to provide integrated door-to-door service, and integration and co-ordination with land-based logistics operations with corresponding factors loading of 0.701 and 0.681 respectively. Carriers' ability to provide integrated door-to-door service has a higher loading factor of 0.701 and its associated median response of 5 (very important).

Door-to-door service and landside logistics integration are crucial for Tasmania island state. This result is consistent with the findings of (Carious 2008; Fanam, Fanam et al., 2016b; Meixell \& Norbis 2008), suggesting this new paradigm should be explored by the ocean freight services providers. Significantly, door-to-door service capability was considered very important by the respondents. 


\section{Cargo}

Cargo factors consisted of four item statements of whether carriers have cargo capacity available throughout the year but most importantly during the peak period and that carriers must provide cargo security and safety throughout the period that the cargo was in their possession. Seasonal capacity availability was included in the study in consideration of Tasmania's significant trade in fresh produce. Various cargo handling factors such as refrigerated and fragile cargo handling capability, cargo security and damage rate are very important to Tasmania shippers.

Tasmanian shippers attributed high-level of importance to cargo security and safety with the highest factor loading of 0.872 and the corresponding median of 5, thus, indicating that Tasmania shippers attributed high level of importance to carriers handling of cargoes. Tasmania shippers processed a high volume of fresh produce, therefore, it is of great concerned that they paid more attention to the safety and security of their cargoes. Capacity availability also received a high factor loading of 0.869 with the corresponding median of 4, thus, also showing that Tasmania shippers perceived carriers' cargo space availability all year round very important in their decision making, even though they do they may need more cargo space during the harvest period of the fresh produce. Seasonal capacity availability, cut-off times for cargo at the port were also highly ranked in importance. Refrigerated cargo capability displayed the lowest factor loading (0.851) among the cargo factor items, this is simply due to the cargo type split of respondents.

\section{Corporate social responsibility}

The corporate social responsibility factor comprised of three items namely 'perceived reputation of carrier,' 'carrier's stated or perceived commitment to Tasmanian services' and 'problem-solving capability' with corresponding factor loadings $0.817,0.808$, and 0.795 respectively. Tasmania shippers consider perceived reputation of carriers important when making a decision on which carrier to choose. Likewise, most Tasmania shippers use local based carrier to provide their transportation services over foreign carriers.

Problem-solving capability was also described as very important by the respondents with a factor loading of 0.795 and corresponding median of 5 . These characteristics are interrelated and could be considered to be common attributes of good shipping service, thus, their representation in the data is unsurprising. All the corporate social responsibility items reported a median response of 4 in exception of problem-solving capability with median 5. Thus, denoting that when choosing carriers, Tasmania shippers consider carriers that understand their needs and marking necessary effort to solve them. Ocean carriers should pay attention to shippers needs and make a considerable effort in addressing the needs of shippers in order to attract them to purchase their shipping service.

Tasmania shippers are much concerns about the corporate social responsibility of the liner shipping companies with regards to the contributions that the carriers are making to the Tasmania economy and more importantly carriers' responsibility to the environment. Carriers should take corporate social responsibility issues seriously as this would give them the possibility of winning the trust of shippers and could lead to the 
establishment of long-term competitive advantages. Also, as Tasmania shippers depend on door-to-door services, ocean carriers can leverage corporate social responsibility challenges through collaboration with other stakeholders.

\section{Conclusions and recommendations}

The findings of this paper validated the ocean carrier selection factors from the shippers' perspective. This paper has made theoretical contributions by finding the critical factors influencing the shippers' choice of ocean carriers. The key contributions of this paper are the identification of the level of importance that the Tasmania shippers attributed to the carrier selection criteria. Common price and service-based decision criteria have been examined in the context of Tasmanian shippers. Service-based factors returned higher factor loadings and corresponding higher median response score, price factor received less important from Tasmania shippers. The findings from Tasmania context revealed different pattern compared to similar studies conducted in other developed countries. Tasmania shippers attributed high-level of importance to service-based factors, that is, cargo safety \& security and capacity availability mainly due to the limited number of transport operators providing services between Tasmania and the mainland (Melbourne). Even though freight rates are high in Tasmania, nevertheless, Tasmania shippers do not attribute high level of importance to pricing. Despite the support of the Tasmanian freight equalisation scheme the freight rates in Tasmania are higher by all standard compare to the mainland counterpart. Notwithstanding, Tasmania shippers do not consider cost as the most critical factor in their decision making in choosing ocean carriers.

The data collected provided valuable insight into the decision criteria of Tasmanian shippers. The factors identified in this paper concur with the findings of previous researchers, indicating that they are well-supported in academic study. However, the level of important attributed to salient factors by Tasmania shippers are different, indicating different pattern from the level of important perceived by previous studies on salient factors. The results of this paper revealed that the most critical factors influencing Tasmania shippers are cargo safety, follow by network \& schedule, corporate social responsibility, pricing of service and door-to-door service. The results of the EFA revealed that cargo safety is the most critical factor that influenced the choice of ocean carriers from the perspective of Tasmania shippers. Thus, it can be implied that Tasmanian shippers are well aware of the characteristics that form their expectations of shipping services, therefore, any liner operator who wants to attract Tasmania shippers to purchase their shipping service must endeavour to provide a high level cargo safety and security services. The liner operators must try their best to provide a reliable schedule network service as most shippers in Tasmania shipped fresh produce, hence network and schedule reliability is crucial for the shippers to get their produce to the customers in real-time.

Clear recommendations can be derived from the research concerning service attributes in the shipping industry. Cargo service attributes described as very important by shippers have a strong influence on their decision to contract with a certain carrier, regardless of whether the carrier is a vessel operator or an NVOCC such as a freight forwarder. Service providers must, therefore, strive to provide cargo capacity available throughout the year and most importantly guarantee from service providers of cargo 
space during the seasonal period. Service provider must also try their best schedule reliability as the importance of schedule service reliability is arguably compounded in a small freight market reliant on maritime transportation, and exhibiting strong competition between service providers. This is the case in Tasmania.

The liner shipping companies can use the findings of this paper as a marketing strategy to channel their resources into the appropriate service area in order to attract shippers to patronise their liner service. According to the findings of this paper, it is recommended that the liner shipping companies should channel their resources to the most important factors identified in this paper to improve those service areas in order to increase their market share in the Tasmania liner shipping sector.

The paper is limited due to the small sample size, making it difficult to draw inference on the general population. In addition, statistical comparison could have been made between participants and the categories of decision criteria, for example, comparing those who use freight forwarding services against those who book directly with the carrier using selected decision criteria.

Future research is recommended. Specifically, connection could be made between users of freight forwarding services and specific price and service-based criteria. The same analysis could be conducted on those who book directly with the ocean carrier. Moreover, additional research into door-to-door freight services in the context of Tasmanian shippers is warranted even though this factor received less important from the response provided to this study. However, the increasing supply chain integration observed in container shipping necessitate the need for this attribute to be considered for future research.

Abbreviations

EFA: Exploratory Factor Analysis; NVOCC : Non-Vessel Owning Common Carrier; TEU : Twenty-Foot Equivalent Unit

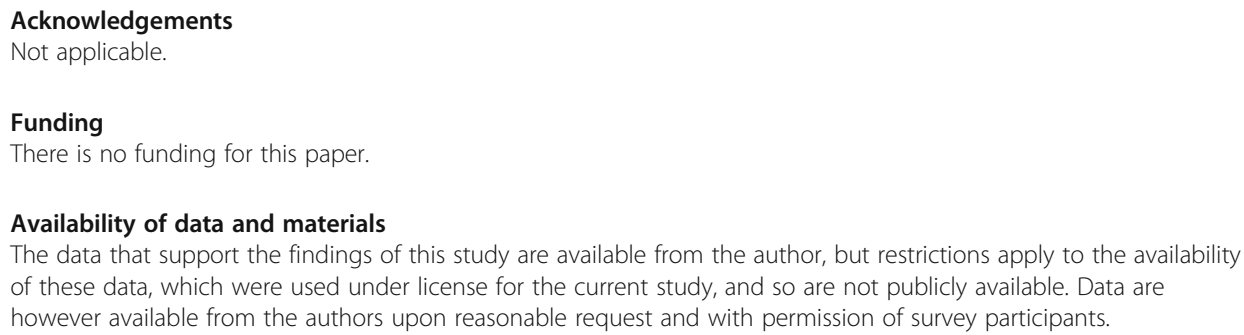

LA performed the data collection and literature review. PDF conducted literature review, analysed and interpreted the data regarding the carrier selection factor, and was a major contributor in writing the manuscript. Both authors read and approved the final manuscript.

Authors' information

Not applicable.

Competing interests

The authors declare that they have no competing interests" in this section.

\section{Publisher's Note}

Springer Nature remains neutral with regard to jurisdictional claims in published maps and institutional affiliations.

\section{Author details}

${ }^{1}$ University of Tasmania the Australian Maritime College, Australia, 28 Treherne Street, Launceston, Tasmania 7248, Australia. ${ }^{2}$ University of Tasmania the Australian Maritime College, Australia, Maritime Drive, Newnham, Tasmania 7248, Australia. 
Received: 21 January 2019 Accepted: 11 April 2019

Published online: 11 July 2019

\section{References}

Albanese A (2012) Findings and recommendations in relation to Tasmanian ports and shipping, Canberra: Australian government. Viewed 2. November 2017

Australian Bureau of Statistics 2019, Australian Demographic Statistics. Australian Government, viewed 23 January 2019 https:// www.abs.gov.au/ausstats/abs@.nsf/Latestproducts/3101.0Main\%20Features2Dec\%202018?opendocument\&tabname= Summary\&prodno=3101.0\&issue $=$ Dec\%202018\&num $=\& v i e w=$

Australian government, viewed 28 September 2017, https:/infrastructure.gov.au/transport/programs/maritime/tasmanian/ index.aspx

Banomyong R, Supatn N (2011). Selecting logistics providers in Thailand: a shippers' perspective. Eur. J. Market. 45(3): 419-437.

Ballantyne S (2014) The education of an innocent Australian. Ausmarine 36:10

Bendall HB, Brooks MR (2010) Short sea shipping: lessons for or from Australia? International journal of shipping and transport logistics, Vol 3, Iss 4

Berg, C. 2017. Regulation and red tape in a small open economy: an Australian overview. Accessed 18/8/2017 https://papers. ssrn.com/Sol3/papers.cfm?abstract_id=2965093

BITRE, 2015. Australian government response to the productivity commission inquiry report on Tasmanian shipping and freight. Media release. Department of infrastructure and regional development assessed 22 August 2017.

Brand Tasmania/Tasmanian Government 2017, Buy from Tasmania Directory, Brand Tasmania, viewed 28 September 2017, < https://www.foodandbeveragetasmania.com/directory/>

Brindley, M. 2016. Coastal shipping reform considerations for Tasmania. Regional development, Australia, Tasmania. Accessed 18/8/2017 https://www.rdatasmania.org.au/client-assets/documents/ Coastal\%20Shipping\%20Reform\%20Considerations\%20for\%20Tasmania\%20WEB\%2009112016.pdf

Brooks M (1990) Ocean carrier selection in a new environment. Logistics and Transportation Review 26(4):339-355

Brooks M (1995) Understanding the ocean container market-a seven country study. Maritime Policy and Management 22(1):39-49

Brooks MR (2014) The changing regulation of coastal shipping in Australia. Ocean Development \& International Law 45:67-83

Brooks MR (2015) Shipping regulation, trade realities and social license: will Short Sea shipping ever be more than just a niche service? Canadian transportation research forum 50th annual conference-another 50 years: where to from here?// un autre 50 ans: qu'en Est-il à partir de maintenant? Montreal, Quebec. May 24-26(2015):2015

Cariou P (2008) Liner shipping strategies: an overview. International Journal of Ocean Systems Management 1(1):2-13

Chung CC, Chiang CH (2011) The critical factors: an evaluation of schedule reliability in liner shipping. International Journal of Operations Research 8(4):1-8

Deegan, M. 2012. Tasmanian port and freight strategy report. Letter to the Honerable senator Anthony Albanese MP. Minister for infrastructure and transport. Accessed 22/8/2017 http://infrastructureaustralia.gov.au/policy-publications/publications/ files/Tasmanian_ports_and_freight_strategy_report.pdf

Department of Foreign Affairs and Trade (DFAT) 2017, Australia's trade by state and territory 2015-16, Annual Report

Department of State Growth (Tasmania) 2015, Information Paper 3: Tasmanian Sea Freight, viewed 12 August 2017, http:// stategrowth.tas.gov.au/_data/assets/pdf_file/0008/127277/Info_Paper_4._Tasmanian_sea_freight.pdf

Department of State Growth (Tasmania) 2019, Tasmanian Sea Freight, viewed 29 January 2019, https://www.stategrowth.tas.gov.au/.

Fanam, PD, Nguyen, H-O, Cahoon, S 2016a, 'Selection of liner operators from the freight forwarders' perspective: methodological issues and framework', international associations of maritime economics (IAME 2015)

Fanam, PD, Nguyen, H-O, Cahoon, S 2016b, 'Competitiveness of the liner operators: methodological issues and implications, Journal of Traffic and Transportation Engineering, no 4, pp. 231-241

Fanam PD, Nguyen H-O, Cahoon S (2016c) Selection of container carriers: one country's perspective. Afr J Bus Manag 10(23): $576-584$

Hidding, R 2016, Tasmanian integrated freight strategy, state growth, viewed 13th September 2017, http://www.stategrowth. tas.gov.au/_data/assets/pdf_file/0017/134216/Tasmanian_Integrated_Freight_Strategy_Part_one.pdf

Kannan V, Bose SK, Kannan NG (2010) Improving the service quality of ocean container carriers: an Indian case study. Benchmarking: An International Journal 19(6):709-729

Kelly, M 2016, Renewed calls for international shipping terminal in Tasmania, ABC news, viewed 24 July 2017, <http://www.abc net.au/news/rural/2016-03-10/renewed-calls-for-international-shipping-terminal-in-tasmania/7236032>

Kent JL, Parker SR (1999) International containership carrier selection criteria: shippers/carriers differences. International Journal of Physical Distribution \& Logistics Management 29(6):398-408

Maloni, MJ, Gligor, DM, Lagoudis, IN (2013), Linking ocean container carrier capabilities to shipper-carrier relationships: a case study, Maritime Policy \& Management 43(8):959-975.

Meixell MJ, Norbis M (2008) A review of the transportation mode choice and carrier selection literature. The International Journal of Logistics Management 19(2):183-211

Mounster, B 2017, Tasmanian exporters to benefit from new Bass Strait shipping service, the mercury, viewed 23 July 2017.

Pearson R (1980) Container Line Performance and Service Quality, University of Liverpool Marine Transport Centre. Liverpool, UK

Porter J (2015) Australian coastal shipping: navigating regulatory reform. Austl \& NZ Mar L 29:8

Premeaux SR (2007) Motor carriers and shippers perceptions of the carrier choice decision. Journal of the Transportation Research Forum 46(3):5-12

Saldanha JP, Tyworth JE, Swan PF, Russell DM (2009) Cutting logistics costs with ocean carrier selection. J Bus Logist 30(2): 175-195

Setamanit S, Pipatwattana A (2015) Criteria for ocean freight carrier selection: a perspective of Japanese automotive company in Thailand. AsBBS eJournal 11(1):89-96

Shang KC, Lu CS (2012) Customer relationship management and firm performance: an empirical study of freight forwarding services. Journal of Marine Science Technology 20(1):64-72 
Tasmania Department of State Growth 2019, Tasmanian Sea Freight, viewed 3 February 2019, https://www.stategrowth.tas. gov.au/transport_services.

Tavakol, M, Dennick, R 2011, 'Making sense of Cronbach's alpha' International Journal of Medical Education, no 2, pp. 53-55

Tiwari P, Itoh H, Doi M (2003) Shippers port and carrier selection behaviour in China: a discrete choice analysis. Maritime Economics \& Logistics 5:23-39

Wong PC, Yan H, Bamford C (2008) Evaluation of factors for carrier selection in the China Pearl River delta. Marit Policy Manag 35(1):27-52

Submit your manuscript to a SpringerOpen ${ }^{0}$ journal and benefit from:

- Convenient online submission

- Rigorous peer review

- Open access: articles freely available online

- High visibility within the field

- Retaining the copyright to your article

Submit your next manuscript at $\boldsymbol{\nabla}$ springeropen.com 